\title{
Human Health Risk Assessment of Heavy Metals in Kampala (Uganda) Drinking Water
}

\author{
Michael Bamuwamye ${ }^{1,2}$, Patrick Ogwok ${ }^{1}$, Vivian Tumuhairwe ${ }^{1}$, Richard Eragu $^{2}$, Henriettah Nakisozi $^{1}$ \& Patrick \\ E. Ogwang ${ }^{3}$ \\ ${ }^{1}$ Kyambogo University, Department of Food Technology, P. O. Box 1, Kyambogo, Kampala \\ ${ }^{2}$ Ministry of Health, Natural Chemotherapeutics Research Institute (NCRI), P. O. Box 4864, Kampala, Uganda \\ ${ }^{3}$ Mbarara University of Science and Technology, P. O. Box 1410, Mbarara, Uganda \\ Correspondence: Patrick Ogwok, Kyambogo University, Department of Food Technology, P. O. Box 1, \\ Kyambogo, Kampala. E-mail: ogwokp@yahoo.com
}

Received: April 23, 2017

Accepted: May 20, 2017 Online Published: June 4, 2017

doi: $10.5539 /$ jfr.v6n4p6

URL: https://doi.org/10.5539/jfr.v6n4p6

\begin{abstract}
Levels of aluminium, arsenic, cadmium, chromium, copper, iron, mercury, manganese, nickel, lead and zinc in tap water, groundwater-fed protected spring and bottled water were determined. The cancer and non-cancer risks associated with ingestion of heavy metals (HM) were also assessed for both children and adults. Forty seven water samples obtained from five divisions of Kampala city were analyzed using atomic absorption spectrophotometry. Cancer and non-cancer risks were determined using incremental lifetime cancer risk (ILCR) and non-carcinogenic hazard quotient (HQ), respectively. Lead content was higher than permissible limits (PL) according to East African Standard, World Health Organization, European Union and United States Environmental Protection Agency (USEPA). Arsenic showed minor exceedances above guideline values in tap water and groundwater-fed protected spring, whereas mercury, manganese and nickel were higher than PL. Levels of aluminium, cadmium, chromium, copper, iron, and zinc were below the PL. The lifetime risk of developing cancer through the oral route was greater than the USEPA acceptable level for both children and adults, revealing that exposure to HM in drinking water posed an unacceptable potential cancer risk. Arsenic contributed ca. $90 \%$ of the ILCR in tap water and groundwater-fed protected spring. The combined non-cancer risk of the HM expressed as hazard index (HI) was greater than one, with values for children being higher than those for adults. Lead contribution towards HI was in all cases above $90 \%$. These results demonstrate the presence of alarming non-cancer risks for children.
\end{abstract}

Key words: heavy metal, risk, cancer, non-cancer, drinking water

\section{Introduction}

Environmental contamination and human exposure to heavy metals (HM) such as mercury ( $\mathrm{Hg}$ ), cadmium (Cd), lead $(\mathrm{Pb})$, arsenic $(\mathrm{As})$ and nickel $(\mathrm{Ni})$, is a serious problem throughout the world (Orisakwe, 2014). Heavy metals accumulate in the environment through emissions from industries, industrial effluents, use of leaded gasoline and paints, agricultural activities, indiscriminate disposal of municipal wastes and incineration of toxic substances (Muwanga \& Barifaijo, 2006). African countries, including Uganda, are nowadays faced with a crisis of industrial waste management due to absence or weak guidelines on HM pollution and environmental management (Okot-Okumu \& Nyenje, 2011). Generated waste, in Uganda, is estimated between 1.2 and 3.8 $\mathrm{kg} / \mathrm{capita} / \mathrm{day}$. Barriers to proper urban waste management also include lack of funds and poor governance (Oosterveer \& Van Vliet, 2010). Therefore, reforms to build institutional capacity in order to mitigate the rapid buildup of HM in aquatic ecosystems in African countries are essential. So far, decentralization has been proposed to involve local actors in the environmental and natural resource management in Africa (Oosterveer \& Van Vliet, 2010).

Human exposure to toxic metals is a global environmental health burden. Arsenic, $\mathrm{Pb}, \mathrm{Hg}$ and $\mathrm{Cd}$ are systemic environmental toxicants that have been implicated in causing cancer, neurological and cardiac problems, and kidney damage (Fernández-Luqueño et al., 2013). In Uganda, $\mathrm{Pb}$ and $\mathrm{Cd}$ levels in excess of WHO limits have been reported in edible vegetables from the Lake Victoria basin wetlands (Mbabazi, Wasswa, Kwetegyeka, \& 
Bakyaita, 2010). Lead and Hg have been detected in African fish eagles, Marabou storks and Nile perch (Hollamby et al., 2004; Ogwok, Muyonga \& Sserunjogi, 2009). Further, high levels of $\mathrm{Pb}$ and $\mathrm{Cd}$ have been reported in milk from farms in Wakiso district (Nyakairu, Muhwezi \& Biryomumaisho, 2011). Based on the adverse effects of HM, information on their levels in drinking water is required to guide policy.

Access to safe drinking water contributes directly to good health, food security, poverty eradication and the long-term socio-economic development of a country (Opio, 2012). Many studies have been conducted in reference to the concentration and potential health risks associated with toxic metals, as well as necessary elements in surface, ground and bottled waters around the world (Hadiani, Dezfooli-manesh, Shoebi, Ziarati, \& Khaneghah 2014; Kolawole \& Obueh, 2015). However, there is limited data on both the chemical water quality monitoring and human health risk assessment (HHRA) of HM in drinking water in Uganda. Therefore, the objectives of this study were to determine the concentration of aluminium ( $\mathrm{Al})$, chromium $(\mathrm{Cr})$, iron $(\mathrm{Fe})$, manganese $(\mathrm{Mn}), \mathrm{As}, \mathrm{Cd}, \mathrm{Cu}, \mathrm{Hg}, \mathrm{Ni}, \mathrm{Pb}$ and $\mathrm{Zn}$ contained in tap water, groundwater-fed protected spring and selected brands of bottled water in Kampala city. The cancer and non-cancer risks associated with ingestion of HM from the daily water consumption were also assessed.

\section{Materials and Methods}

\subsection{Study Area}

The study area was Kampala, the Capital City of Uganda. The city lies at latitude $0.3476^{\circ} \mathrm{N}$ and longitude $32.5825^{\circ} \mathrm{E}$, and $1223 \mathrm{~m}(4012 \mathrm{ft})$ above sea level. It covers a total area of 189 square kilometers (73 sq. miles) with a radius of $6 \mathrm{~km}$. Kampala has a tropical climate with an average annual temperature of $21.3{ }^{\circ} \mathrm{C}$, and average annual rainfall of $c a .1,400 \mathrm{~mm}$, with peaks in April and November.The resident population of Kampala is estimated to be 1,936,080 ( 0.78 male: 1.0 female) inhabitants of whom $16 \%$ are children 5 to 9 years of age (UBOS, 2016). Sixty percent of Kampala's population resides and or works within the peri-urban areas of the city. Most peri urban areas are low lying (mostly reclaimed wetlands) with a high water table $(<1.5 \mathrm{~m})$.

\subsection{Materials}

Analytical grade nitric acid (Sigma-Aldrich) was used in the study. Distilled water was used to prepare solutions and for dilution purposes. All glassware were washed and dried in the oven at $105^{\circ} \mathrm{C}$. Bottles for collecting water samples were cleaned by soaking in dilute nitric acid (10\%) and rinsed several times with distilled water prior to sample taking. Water samples were obtained from public water-taps and groundwater-fed protected springs around Kampala. Bottled water was purchased from different places in the city.

\subsection{Sample Collection}

Samples of water were randomly obtained from 8 public water taps and 12 groundwater-fed protected springs in the five divisions of Kampala, within a radius of $5 \mathrm{~km}$ from the city center. Three samples, each of $500 \mathrm{ml}$, were obtained per sampling point. Also, 3 samples of each of 9 bottled water brands were purchased from local shops, supermarkets and public transport stations. Sampling was done between September and November 2015.

\subsection{Determination of Heavy Metals}

Levels of metals in water were determined on a Shimadzu Electro-thermal Graphite Furnace Atomic Absorption Spectrophotometer (GF-AAS) equipped with High-speed Deuterium (BGC-D2) and Self-Reversal method background correction (BGC-SR) along with an ASC6100 auto-sampler (Shimadzu Corporation, Japan). Analysis was done at the Natural Chemotherapeutics Research Institute (NCRI) chemistry laboratory. Standard solutions of the respective metals were prepared at 5 different concentrations and the absorbance (A) determined. A calibration curve was in each case generated. The calibration curves were linear within the range of concentrations used, with regression coefficients $\left(\mathrm{R}^{2}\right)>99.9 \%$. Each of the water samples was aspirated into the AAS and the absorbance measured was used to determine the concentration of the metal from the calibration curve. This procedure was repeated three times and the average concentration obtained. Analysis was done at wavelength ( $\lambda$ ) 309.3, 193.7, 228.8, 357.9, 324.8, 248.3, 253.7, 279.5, 232.0, 283.3, and $213.9 \mathrm{~nm}$ for Al, As, Cd, $\mathrm{Cr}, \mathrm{Cu}, \mathrm{Fe}, \mathrm{Hg}, \mathrm{Mn}, \mathrm{Ni}, \mathrm{Pb}$ and $\mathrm{Zn}$, respectively. The metal concentrations expressed as $\mathrm{mg} / \mathrm{L}$, were compared with permissible limits for HM in drinking water set by East African Community (EAC), United States Environment Protection Agency (USEPA), World Health Organization (WHO) and the European Union (EU) shown in Table 1. 
Table 1. Permissible limits of heavy metal concentrations $(\mathrm{mg} / \mathrm{L})$ in drinking water for different international agencies

\begin{tabular}{llllllllllll}
\hline \multicolumn{1}{c}{ Agency } & \multicolumn{10}{c}{ Element } \\
\cline { 2 - 13 } & $\mathrm{Al}$ & $\mathrm{As}$ & $\mathrm{Cd}$ & $\mathrm{Cr}$ & $\mathrm{Cu}$ & $\mathrm{Fe}$ & $\mathrm{Hg}$ & $\mathrm{Mn}$ & $\mathrm{Ni}$ & $\mathrm{Pb}$ & $\mathrm{Zn}$ \\
\hline EU (1998) & 0.2 & 0.01 & 0.005 & 0.05 & 2 & 0.2 & 0.001 & 0.05 & 0.02 & 0.01 & - \\
WHO (2008) & 0.2 & 0.01 & 0.003 & 0.05 & 2 & 0.3 & 0.006 & 0.4 & 0.07 & 0.01 & 3 \\
USEPA (2009) & 0.2 & 0.01 & 0.005 & 0.1 & 1 & 0.3 & 0.002 & 0.05 & 0.1 & 0.015 & 5 \\
UNBS (2014) & 0.2 & 0.01 & 0.003 & 0.05 & 1 & 0.3 & 0.001 & 0.1 & 0.02 & 0.01 & 5 \\
\hline
\end{tabular}

\subsection{Human Health Risk Assessment}

Human health risk assessment (HHRA) involves estimation of the nature and magnitude of adverse health effects in humans who may be exposed to hazards in contaminated environmental media. Risk assessment consisted of hazard identification, exposure assessment, dose-response (toxicity) and risk characterization (Adamu, Nganje, \& Edet, 2015). The health risk assessment of each potentially toxic HM was done based on the quantification of the risk level and expressed in terms of cancer and non-cancer health risks (Sun, Zhang, Ma, \& Chen, 2015). Two toxicity risk indices reported were the cancer slope factor (CSF) for cancer risk characterization and the oral reference dose (RfD) for non-cancer risk characterization (Adamu, Nganje, \& Edet, 2015).

\subsubsection{Exposure Assessment}

In order to assess both non-cancer and cancer risks for children and adults from ingestion of drinking water, the chronic daily intakes (CDI) of toxic metals, which represents the lifetime average daily dose (LADD) of exposure to a chemical contaminant were used (Yu, Wang, \& Zhou, 2014). The CDI $\left(\mathrm{mgkg}^{-1} \mathrm{day}^{-1}\right)$ of toxic metals via water was calculated using equation 1 :

$$
\mathrm{CDI}=(\mathrm{C} \times \mathrm{IR} \times \mathrm{EF} \times \mathrm{ED}) /(\mathrm{BW} \times \mathrm{AT})
$$

where: CDI is the chronic daily intake $(\mathrm{mg} / \mathrm{kg} / \mathrm{day}) ; \mathrm{C}$ is the concentration of the contaminant in tap, groundwater-fed protected spring and bottled water $(\mathrm{mg} / \mathrm{L})$; IR is the ingestion rate per unit time $(1 \mathrm{~L} /$ day for child and 2L/day for adult); ED is the exposure duration (6 years for child and 30 years for adult); EF is the exposure frequency ( 365 days/year); BW is body weight (15 kg for child and $70 \mathrm{~kg}$ for adult); AT is the averaging exposure time (for carcinogens, AT $=70 \times 365=25550$ days for both children and adults; for non-carcinogens, $\mathrm{AT}=\mathrm{ED} \times 365$ which equals 2190 days and 10950 days for children and adults, respectively) (USEPA, 1989).

\subsubsection{Non-cancer Risks}

Non-cancer risks due to non-carcinogenic effects of HM in drinking water were determined by the non-cancer hazard quotient using equation 2 :

$$
\mathrm{HQ}=\mathrm{CDI} / \mathrm{RfD}
$$

where: $\mathrm{HQ}=$ non-cancer hazard quotient; $\mathrm{CDI}=$ chronic daily intake (mg metal $/ \mathrm{kg} /$ day); $\mathrm{RfD}=$ chronic oral reference dose, which is an estimate of a daily oral exposure level for the human population, including sensitive subpopulations, that is likely to be without an appreciable risk of deleterious effects during a lifetime (Bamuwamye, Ogwok, \& Tumuhairwe, 2015).

Potential risk to human health through more than one HM, was measured by the chronic hazard index (HI), which is the sum of all HQ calculated for individual HM ( $\mathrm{Li}$, et al., 2013). A value of HQ or HI < 1 implies no significant non-cancer risks; a value $\geq 1$ implies significant non-cancer risks, which increase with increasing value of HQ or HI (Wei, et al., 2015).

\subsubsection{Cancer Risks}

Cancer risks were expressed in terms of incremental lifetime cancer risk (ILCR), which is the probability that one may develop cancer over a 70-year lifetime due to a 24 hour exposure to a potential carcinogen (Adamu, Nganje, \& Edet, 2015). Cancer risk was calculated as the product of CDI (mg/kg-day) and cancer slope factor (CSF) measured in $(\mathrm{mg} / \mathrm{kg} / \mathrm{day})^{-1}$. The latter is the risk produced by a lifetime average dose of $1 \mathrm{mg} / \mathrm{kg}$ body weight/day of a contaminant. Cancer risk was calculated as follows (Adamu, Nganje \& Edet, 2015):

$$
\mathrm{ILCR}=\mathrm{CDI} \mathrm{X} \text { CSF }
$$

where: $\mathrm{ILCR}=$ incremental lifetime cancer risk; $\mathrm{CDI}=$ chronic daily intake $(\mathrm{mg} / \mathrm{kg} \mathrm{BW} /$ day $)$; $\mathrm{CSF}=$ cancer slope factor $(\mathrm{mg} / \mathrm{kg} / \mathrm{day})^{-1}$. 
The total cancer risk as a result of exposure to multiple contaminants due to consumption of a particular type of water was assumed to be the sum of the individual metal incremental risks ( $\sum$ ILCR, $n=1$ to $n$ ). The USEPA considers the minimum or acceptable cancer risk for regulatory purposes within the range of $1 \times 10^{-6}$ to $1 \times 10^{-4}(\mathrm{Li}$ et al., 2013).

\section{Results and Discussion}

\subsection{Heavy Metal Concentration in Drinking Water}

\subsubsection{Tap Water}

Levels of $\mathrm{Pb}$ in tap water ranged from 0.017 to $0.31 \mathrm{mg} / \mathrm{L}$ (Table 2). Arsenic was detected in substantial amounts ( 0.005 to $0.014 \mathrm{mg} / \mathrm{L})$ while $\mathrm{Cu}$ concentrations $(0.006$ to $0.036 \mathrm{mg} / \mathrm{L})$ were low. Lead and As concentrations were above the $0.01 \mathrm{mg} / \mathrm{L}$ limit prescribed for either metal by WHO, EAC and EU. Manganese concentration ranged from not detected to $0.337 \mathrm{mg} / \mathrm{L}$. The levels of $\mathrm{Mn}$ in tap water were therefore below the maximum allowable limit set by WHO. However, two sampled water taps had Mn level above EU, EAC, and USEPA recommendations (Table 1). Nickel concentration (not detected to $0.17 \mathrm{mg} / \mathrm{L}$ ) was higher than all maximum allowable limits considered in this study. Mercury concentration in tap water was below WHO recommendations but above USEPA, EU and EAC limits. The concentrations of $\mathrm{Fe}$ and $\mathrm{Zn}$ were rather low. Aluminium and $\mathrm{Cd}$ were not detected in all the samples.

Lead levels in tap water in Kampala were lower than previously reported in the East Africa region (Table 5). Lead in tap water is possibly a result of corrosion of older fixtures or from the solder that connects pipes (Gaur, Singh, \& Saxena, 2011). Polyvinyl chloride (PVC) pipes, used on the national water supply grid in Uganda, and for domestic water supply around Kampala, also contain $\mathrm{Pb}$ compounds as cost effective form of stabilizer. Lead can leach into the water when it flows through leaded pipes for several hours. Similarly, Ni has its origin in pipes and installations (Sankar \& Rao, 2014). This explains the observed levels of $\mathrm{Pb}$ and $\mathrm{Ni}$ in the tap water in Kampala city. Arsenic, $\mathrm{Mn}$ and $\mathrm{Hg}$ have been reported in high concentrations in drinking water in Africa (Ahoulé, Lalanne, Mendret, Brosillon, Maiga, 2015). In Kampala, As, Mn and Hg found in water may be related to sand mining operations, agricultural drains, improper waste disposal, and incineration of toxic wastes around Lake Victoria (Muwanga \& Barifaijo, 2006; Okot-Okumu \& Nyenje, 2011). Tap water contamination by Hg could be linked to gold mining reported along Lake Victoria shores (Van Straaten, 2000). On the other hand, drinking water naturally contains very low amounts $(0.01$ to $0.05 \mathrm{~g} / \mathrm{L})$ of $\mathrm{Cr}$ except for regions with substantial deposits (Mebrahtu \& Zerabruk, 2011). Drinking water seldom contains $\mathrm{Zn}$ at concentrations $>0.1 \mathrm{mg} / \mathrm{litre}$, but high levels in tap water can be due to leaching from older galvanized plumbing materials. Low amounts of $\mathrm{Cd}$ in tap water could be due to coagulation or precipitation used in municipal water treatment that reduces $\mathrm{Cd}$ concentration to levels $\leq 0.002 \mathrm{mg} /$ litre. These factors support the observed levels of $\mathrm{Cr}, \mathrm{Zn}$ and $\mathrm{Cd}$ in tap water in Kampala.

Table 2. Concentration (mg/L) of heavy metals in Tap water $(\mathrm{mg} / \mathrm{L})$ in Kampala

\begin{tabular}{lllllllllll}
\hline \multirow{2}{*}{ Metal } & \multicolumn{7}{c}{ Water tap $(\mathrm{n}=08)$} & \multirow{2}{*}{ Minimum } & \multirow{2}{*}{ Maximum } \\
\cline { 2 - 7 } $\mathrm{Al}$ & 1 & 2 & 3 & 4 & 5 & 6 & 7 & 8 & & \\
$\mathrm{As}$ & 0.014 & 0.005 & 0.009 & 0.011 & 0.011 & 0.013 & 0.010 & 0.011 & 0.005 & 0.014 \\
$\mathrm{Cd}$ & n.d. & n.d. & n.d. & n.d. & n.d. & n.d. & n.d. & n.d. & n.d. & n.d. \\
$\mathrm{Cr}$ & n.d. & n.d. & n.d. & n.d. & 0.026 & 0.034 & n.d. & n.d. & n.d. & 0.034 \\
$\mathrm{Cu}$ & 0.008 & 0.036 & 0.014 & 0.024 & 0.017 & 0.019 & 0.032 & 0.006 & 0.006 & 0.036 \\
$\mathrm{Fe}$ & n.d. & n.d. & n.d. & n.d. & n.d. & n.d. & 0.029 & 0.029 & n.d. & 0.029 \\
$\mathrm{Hg}$ & 0.002 & n.d. & n.d. & 0.001 & 0.002 & 0.002 & 0.001 & 0.003 & n.d. & 0.003 \\
$\mathrm{Mn}$ & n.d. & 0.337 & n.d. & n.d. & n.d. & n.d. & 0.297 & n.d. & n.d. & 0.337 \\
$\mathrm{Ni}$ & 0.096 & n.d. & n.d. & 0.029 & 0.058 & 0.170 & 0.163 & 0.04 & n.d. & 0.170 \\
$\mathrm{~Pb}$ & 0.178 & 0.192 & 0.266 & 0.192 & 0.178 & 0.017 & 0.310 & 0.090 & 0.017 & 0.310 \\
$\mathrm{Zn}$ & 0.756 & n.d. & n.d. & n.d. & n.d. & n.d. & n.d. & n.d. & n.d. & 0.756 \\
\hline
\end{tabular}

n.d.: not detected

\subsubsection{Groundwater-fed Protected Spring}

Lead and As were in concentrations ranging from 0.105 to $0.412 \mathrm{mg} / \mathrm{L}$ and 0.008 to $0.014 \mathrm{mg} / \mathrm{L}$, respectively (Table 3). Arsenic showed minor exceedances above guideline values in groundwater-fed protected spring while $\mathrm{Pb}$ was well above the prescribed limit of $0.01 \mathrm{mg} / \mathrm{L}$ according to WHO, USEPA, EU and EAC (Table 1). 
Mercury concentration of not detected to $0.004 \mathrm{mg} / \mathrm{L}$ implies that all springs had $\mathrm{Hg}$ level below the WHO limit of $0.006 \mathrm{mg} / \mathrm{L}$. However, the majority of the springs had mercury level above EU and EAC limits. The concentration (not detected to $1.501 \mathrm{mg} / \mathrm{L}$ ) of $\mathrm{Mn}$ in most groundwater-fed protected springs exceeded recommended limits (Table 1). Nickel had a maximum concentration of $0.373 \mathrm{mg} / \mathrm{L}$ with half of the springs having values above WHO, USEPA, EU and EAC limits. Levels of $\mathrm{Pb}, \mathrm{As}, \mathrm{Hg}, \mathrm{Mn}$, and $\mathrm{Ni}$ in groundwater generally exceeded prescribed limits. Chromium, $\mathrm{Cu}, \mathrm{Fe} \mathrm{Al}, \mathrm{Cd}$ and $\mathrm{Zn}$ were in low amounts in groundwater. Chromium was below detection limit with the exception of one spring, which had $\mathrm{Cr}$ concentration above WHO, EAC and EU recommendations. Similarly, the Cu concentrations (not detected to $0.062 \mathrm{mg} / \mathrm{L}$ ) and that of $\mathrm{Fe}$ ranging from not detected to $0.084 \mathrm{mg} / \mathrm{L}$ were low. Aluminium, Cd and $\mathrm{Zn}$ were not detected in groundwater.

Groundwater-fed protected spring contained $\mathrm{Pb}, \mathrm{Cu}, \mathrm{Ni}$ and $\mathrm{Mn}$ concentrations within ranges previously reported for groundwater in Africa (Table 5). On the other hand, $\mathrm{Cr}, \mathrm{Fe}, \mathrm{Al}, \mathrm{Cd}, \mathrm{Zn}$ and As levels were far lower than reported elsewhere. Despite the high toxicity of $\mathrm{Hg}$, it is not widely studied in Africa. However, surface water and borehole water from Nigeria has been reported to contain $\mathrm{Hg}$ concentrations ( 2.179 to 3.148 and 1.38 to $2.806 \mathrm{mg} / \mathrm{L}$, respectively) far above recommended limits (Abdullahi et al., 2016). An increased level of HM in groundwater in Kampala can largely be attributed to indiscriminate disposal and incineration of toxic wastes, large-scale application of agrichemicals, use of lead-based gasoline and dissolution from rocks (Muwanga \& Barifaijo, 2006; Okot-Okumu \& Nyenje, 2011). Solid waste streams including domestic, industrial, healthcare, and commercial sources that contribute to urban waste load in Kampala are poorly managed (Okot-Okumu \& Nyenje, 2011). Lack of appropriate waste disposal, and improper waste management in Kampala allows leakage of heavy metals into groundwater. A national strategy to control inappropriate waste disposal and use of agrichemicals to reduce influx of HM in water is therefore required.

Table 3. Concentration (mg/L) of heavy metals in groundwater-fed protected spring around Kampala

\begin{tabular}{|c|c|c|c|c|c|c|c|c|c|c|c|c|c|c|}
\hline \multirow{2}{*}{ Metal } & \multicolumn{12}{|c|}{ Groundwater-fed protected spring $(\mathrm{n}=12)$} & \multirow{2}{*}{ Minimum } & \multirow{2}{*}{ Maximum } \\
\hline & 1 & 2 & 3 & 4 & 5 & 6 & 7 & 8 & 9 & 10 & 11 & 12 & & \\
\hline $\mathrm{Al}$ & n.d. & n.d. & n.d. & n.d. & n.d. & n.d. & n.d. & n.d. & n.d. & n.d. & n.d. & n.d. & n.d. & n.d. \\
\hline As & 0.011 & 0.009 & 0.008 & 0.01 & 0.01 & 0.009 & 0.01 & 0.013 & 0.008 & 0.014 & 0.012 & 0.008 & 0.008 & 0.014 \\
\hline $\mathrm{Cd}$ & n.d. & n.d. & n.d. & n.d. & n.d. & n.d. & n.d. & n.d. & n.d. & n.d. & n.d. & n.d. & n.d. & n.d. \\
\hline $\mathrm{Cr}$ & n.d. & n.d. & n.d. & n.d. & 0.098 & 0.005 & n.d. & n.d. & n.d. & n.d. & n.d. & n.d. & n.d. & 0.098 \\
\hline $\mathrm{Cu}$ & 0.035 & 0.05 & 0.049 & 0.02 & n.d. & 0.032 & 0.38 & 0.062 & 0.049 & 0.051 & 0.038 & 0.047 & n.d. & 0.062 \\
\hline $\mathrm{Fe}$ & n.d. & n.d. & 0.046 & 0.080 & n.d. & n.d. & 0.084 & 0.058 & 0.005 & n.d. & n.d. & 0.037 & n.d. & 0.084 \\
\hline $\mathrm{Hg}$ & 0.003 & 0.004 & 0.004 & n.d. & n.d. & 0.002 & n.d. & 0.004 & 0.001 & 0.002 & 0.002 & n.d. & n.d. & 0.004 \\
\hline $\mathrm{Mn}$ & n.d. & n.d. & 0.188 & n.d. & 0.712 & n.d. & 0.970 & 0.570 & 1.501 & 0.884 & 1.213 & 0.987 & n.d. & 1.501 \\
\hline $\mathrm{Ni}$ & n.d. & n.d. & n.d. & 0.18 & 0.078 & n.d. & 0.185 & n.d. & 0.21 & 0.179 & n.d. & 0.373 & n.d. & 0.373 \\
\hline $\mathrm{Pb}$ & 0.280 & 0.105 & 0.266 & 0.266 & 0.266 & 0.383 & 0.207 & 0.134 & 0.207 & 0.134 & 0.354 & 0.412 & 0.105 & 0.412 \\
\hline $\mathrm{Zn}$ & n.d. & n.d. & n.d. & n.d. & n.d. & n.d. & n.d. & n.d. & n.d. & n.d. & n.d. & n.d. & n.d. & n.d. \\
\hline
\end{tabular}

n.d.: not detected

\subsubsection{Bottled Water}

Of the eleven elements considered in this study, $\mathrm{Pb}$ and $\mathrm{Cr}$ were detected in bottled water in Kampala city. Lead concentration was in the range of 0.091 to $0.241 \mathrm{mg} / \mathrm{L}$ (Table 4). Chromium was detected in most bottled water brands with concentration of up to $0.107 \mathrm{mg} / \mathrm{L}$. Levels of $\mathrm{Pb}$ in bottled water exceeded prescribed limits by WHO, USEPA, EU and EAC. On the contrary, except for two bottled water brands, the amount of Cr was below permissible limits. In Uganda, bottled water is obtained from a variety of sources including protected underground springs, wells and municipal supplies. The water is filtered through multi-barrier filtration systems, reverse osmosis and micro-filtration. Further treatment may include exposure to ultraviolet light or ozonation. These methods remove up to $80 \%$ of HM, which explains why most elements were not detected in bottled water. However, the methods may probably not remove $\mathrm{Pb}$ and $\mathrm{Cr}$ to that magnitude. Lead levels in this study are within the range of 0.008 to $0.253 \mathrm{mg} / \mathrm{L}$ previously reported for bottled water in Kampala (Semuyaba, Segawa, \& Wamala, 2014). 
Table 4. Concentration (mg/L) of heavy metals in bottled water in Kampala

\begin{tabular}{|c|c|c|c|c|c|c|c|c|c|c|c|}
\hline \multirow{2}{*}{ Metal } & \multicolumn{9}{|c|}{ Bottled water Brand $(n=27)$} & \multirow{2}{*}{ Minimum } & \multirow{2}{*}{ Maximum } \\
\hline & 1 & 2 & 3 & 4 & 5 & 6 & 7 & 8 & 9 & & \\
\hline $\mathrm{Al}$ & n.d. & n.d. & n.d. & n.d. & n.d. & n.d. & n.d. & n.d. & n.d. & n.d. & n.d. \\
\hline As & n.d. & n.d. & n.d. & n.d. & n.d. & n.d. & n.d. & n.d. & n.d. & n.d. & n.d. \\
\hline $\mathrm{Cd}$ & n.d. & n.d. & n.d. & n.d. & n.d. & n.d. & n.d. & n.d. & n.d. & n.d. & n.d. \\
\hline $\mathrm{Cr}$ & 0.0168 & n.d. & n.d. & 0.03 & 0.107 & 0.006 & n.d. & 0.031 & 0.065 & n.d. & 0.107 \\
\hline $\mathrm{Cu}$ & n.d. & n.d. & n.d. & n.d. & n.d. & n.d. & n.d. & n.d. & n.d. & n.d. & n.d. \\
\hline $\mathrm{Fe}$ & n.d. & n.d. & n.d. & n.d. & n.d. & n.d. & n.d. & n.d. & n.d. & n.d. & n.d. \\
\hline $\mathrm{Hg}$ & n.d. & n.d. & n.d. & n.d. & n.d. & n.d. & n.d. & n.d. & n.d. & n.d. & n.d. \\
\hline $\mathrm{Mn}$ & n.d. & n.d. & n.d. & n.d. & n.d. & n.d. & n.d. & n.d. & n.d. & n.d. & n.d. \\
\hline $\mathrm{Ni}$ & n.d. & n.d. & n.d. & n.d. & n.d. & n.d. & n.d. & n.d. & n.d. & n.d. & n.d. \\
\hline $\mathrm{Pb}$ & 0.195 & 0.180 & 0.169 & 0.172 & 0.2 & 0.241 & 0.146 & 0.091 & 0.182 & 0.091 & 0.241 \\
\hline $\mathrm{Zn}$ & n.d. & n.d. & n.d. & n.d. & n.d. & n.d. & n.d. & n.d. & n.d. & n.d. & n.d. \\
\hline
\end{tabular}

n.d.: not detected

Table 5. Levels (mg/L) of heavy metals in drinking water from selected African environments

\begin{tabular}{|c|c|c|c|c|c|c|c|c|c|c|c|c|c|}
\hline \multirow{2}{*}{ Country } & \multirow{2}{*}{ DW source } & \multicolumn{11}{|c|}{ Element } & \multirow{2}{*}{ Reference } \\
\hline & & $\mathrm{Al}$ & As & $\mathrm{Cd}$ & $\mathrm{Cr}$ & $\mathrm{Cu}$ & $\mathrm{Fe}$ & $\mathrm{Hg}$ & Mn & $\mathrm{Ni}$ & $\mathrm{Pb}$ & $\mathrm{Zn}$ & \\
\hline \multirow{3}{*}{ Uganda } & TW & n.d. & $0.005-0.014$ & n.d. & n.d. 0.034 & $0.006-0.036$ & $\begin{array}{l}\text { n.d. }-0.105 \\
\end{array}$ & n.d. -0.003 & n.d. 0.337 & n.d. -0.017 & $0.017-0.31$ & n.d. -0.7558 & \multirow{3}{*}{ This study } \\
\hline & GW & n.d. & $0.008-0.014$ & n.d. & n.d. -0.098 & n.d. -0.062 & n.d. -0.084 & n.d. -0.004 & n.d.-1.501 & n.d. -0.373 & $0.105-0.412$ & n.d. & \\
\hline & $\mathrm{BW}$ & n.d. & n.d. & n.d. & n.d. -0.107 & n.d. & n.d. & n.d. & n.d. & n.d. & $0.091-0.241$ & n.d. & \\
\hline \multirow{2}{*}{ Uganda } & TW & - & - & - & - & - & - & - & - & - & $0.9-1.9$ & - & \multirow{2}{*}{ Mghweno, et al. (2008) } \\
\hline & SW & - & - & - & - & - & - & - & - & - & $3.2-6.1$ & - & \\
\hline Uganda & BW & - & - & - & - & - & - & - & - & - & $0.008-0.253$ & - & Semuyaba, et al. (2014) \\
\hline Uganda & sW & - & - & $0.09-0.11$ & $0.01-0.02$ & $1.0-2.1$ & $15.0-21.1$ & - & - & - & $0.91-1.64$ & $0.20-0.50$ & Fuhrimann, et al. (2015) \\
\hline Kenya & $\mathrm{SW}$ & - & - & - & $0.23-0.79$ & $0.69-0.94$ & - & - & $0.05-3.276$ & - & $0.26-0.99$ & 0.22 & Oyoo-Okoth, et al. (2010) \\
\hline Tanzania & GW & - & - & - & - & n.d. -0.013 & - & - & - & - & $0.01-0.35$ & $0.01-0.28$ & Mkude (2015) \\
\hline Rwanda & Well & - & - & - & - & - & $0.02-0.45$ & - & $0.003-0.42$ & - & - & $0.02-0.15$ & Nigatu et al. (2015) \\
\hline Ethiopia & DW & - & $0.39-1.06$ & n.d. & n.d. & n.d. & $0.134-0.307$ & - & $0.025-0.031$ & n.d. & $0.052-1.347$ & $0.439-5.055$ & Mebrahtu \& Zerabruk (2011) \\
\hline \multirow{2}{*}{ Egypt } & SW & $0.136-0.864$ & - & - & - & $0.003-0.012$ & $0.160-4.03$ & - & $0.001-0.474$ & - & n.d. & - & \multirow{2}{*}{ El-Sayed \& Salem (2015) } \\
\hline & GW & $0.125-1.69$ & - & - & - & $0.0001-0.018$ & $0.40-1.88$ & - & $0.017-1.095$ & - & $0.028-0.179$ & - & \\
\hline \multirow{2}{*}{ Nigeria } & SW & - & - & $0.004-0.011$ & $0.16-1.65$ & - & $0.351-12.0$ & - & $0.10-5.15$ & - & $0.02-2.5$ & - & \multirow{2}{*}{ Afiukwa (2013) } \\
\hline & GW & - & - & $0.004-0.012$ & $0.208-0.29 \beta$ & - & $0.40-1.88$ & - & $0.10-3.34$ & - & $0.028-0.179$ & - & \\
\hline \multirow{2}{*}{ Nigeria } & Well & - & - & n.d. -0.003 & - & n.d. -0.003 & n.d. -3.428 & $2.179-3.148$ & $0.057-0.175$ & n.d. -0.006 & n.d. -0.021 & - & \multirow[t]{2}{*}{ Abdullahi, et al. (2016) } \\
\hline & Borehole & - & - & n.d. -0.056 & - & n.d. -0.193 & $0.228-23.256$ & $1.38-2.806$ & $0.035-1.787$ & n.d. -0.03 & n.d. 0.194 & - & \\
\hline
\end{tabular}

TW: Tap water; BW: Bottled water; SW: Surface water; GW: Ground water; DW: Drinking water; n.d.: not detected

\subsection{Human Health Risk Assessment}

Cancer and non-cancer risks were determined based on the mean concentrations of carcinogenic and non-carcinogenic metals using the incremental lifetime cancer risk (ILCR) and the non-cancer hazard quotient (HQ), respectively (Liu, et al., 2013). Heavy metal mean concentrations, and oral reference doses and cancer slope factors used in the assessment are presented in Table 6. 
Table 6. Mean metal concentrations, oral reference doses and cancer slope factors of the respective heavy metals

\begin{tabular}{llllllllllll}
\hline Metal & $\mathrm{Al}$ & $\mathrm{As}$ & $\mathrm{Cd}$ & $\mathrm{Cr}$ & $\mathrm{Cu}$ & $\mathrm{Fe}$ & $\mathrm{Hg}$ & $\mathrm{Mn}$ & $\mathrm{Ni}$ & $\mathrm{Pb}$ & $\mathrm{Zn}$ \\
\hline Tap water (mg/L) & - & 0.011 & - & 0.03 & 0.019 & 0.054 & 0.002 & 0.079 & 0.07 & 0.178 & 0.094 \\
GWPS (mg/L) & - & 0.010 & - & 0.051 & 0.043 & 0.059 & 0.002 & 0.585 & 0.087 & 0.251 & - \\
Bottled water (mg/L) & - & - & - & 0.025 & - & - & & - & - & 0.175 & - \\
RfD (mg/kg/day)*** & 0.14 & 0.0003 & 0.0005 & 1.5 & 0.04 & 0.7 & 0.0003 & 0.14 & 0.02 & 0.0004 & 0.3 \\
CSF (mg/kg/day) $)^{-1 * *}$ & 0.2 & 1.50 & 6.30 & 42 & - & - & - & - & - & 0.0085 & - \\
\hline
\end{tabular}

GWPS: Groundwater-fed protected spring; RfD: Oral reference dose; CSF: Cancer slope factor (**Source: USEPA, 2016).

\subsubsection{Non-cancer Risks}

Tap water, groundwater-fed protected spring and bottled water had hazard quotient (HQ) values showing unacceptable risk ( $\mathrm{HQ}>1$ ) for $\mathrm{Pb}$ in both children and adults (Table 7). Arsenic in tap water and groundwater-fed protected spring also showed unacceptable risk among children and potential risk in adults. The potential health risk of $\mathrm{Cr}$ was minimal (HQ $<0.001)$ in all the three water types for both adults and children in comparison to other HM investigated (Guerra, Trevizam, Muraoka, Marcante, \& Canniatti-Brazaca, 2012). Hazard quotients for $\mathrm{Al}, \mathrm{Cd}, \mathrm{Cr}, \mathrm{Cu}, \mathrm{Fe}, \mathrm{Hg}, \mathrm{Mn}, \mathrm{Ni}$ and $\mathrm{Zn}$ were $<1$ for tap water, groundwater-fed protected spring and bottled water signifying that the population would not experience non-cancer risks due to exposure to these metals in drinking water. Hazard Index (HI) values of the heavy metals for groundwater-fed protected spring, tap water and bottled water for children were 50.226, 36.372, and 32.409, respectively. For adults, HI values of 21.525 for groundwater, 15.588 for tap water and 13.889 for bottled water were obtained. Hazard indices $>1$ were obtained in all water samples, indicating unacceptable risk for non-carcinogenic adverse health effect.

Lead contributed most towards exposure to non-cancer risks in the exposed population followed by As. A HQ value of $1<\mathrm{HQ}<5$ indicates a level of concern while a value of $10<\mathrm{HQ}<100$ suggests need for additional data gathering. This study therefore shows that As was in a level of concern in tap water and groundwater, while $\mathrm{Pb}$ needed further data collection. Hazard indices for children were higher than those for adults meaning that children would experience more non-cancer risks than adults. Young children absorb chemicals four times more than adults (Akkus \& Ozdenerol, 2014). Similar observations have been reported (Guerra et al., 2012; Bamuwamye, Ogwok, \& Tumuhairwe, 2015).

Table 7. Chronic daily intakes and Non-cancer hazard quotients for children and adults, by metal and water-type for drinking water in Kampala city

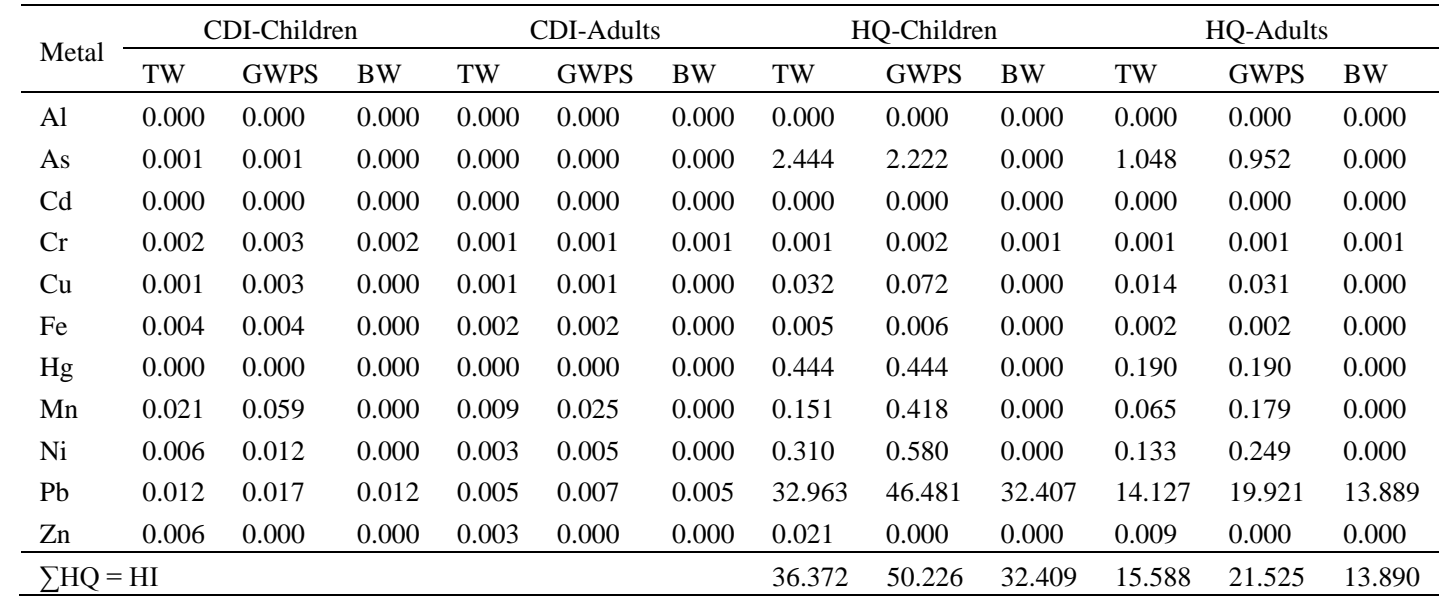

TW: Tap water; GWPS: Groundwater-fed protected spring; BW: Bottled water; CDI: Chronic daily intakes; HQ: Hazard quotient; HI: Hazard Index

\subsubsection{Cancer Risks}

Lifetime cancer risk through ingestion of $\mathrm{Pb}$ and $\mathrm{As}$ was $9.90 \times 10^{-5}$ and $2.12 \times 10^{-4}$ for tap water; $9.79 \times 10^{-5}$ and $2.10 \times 10^{-4}$ for groundwater; $8.50 \times 10^{-6}$ and $1.82 \times 10^{-5}$ for bottled water (Table 8 ), for children and adults, respectively. These results indicate higher cancer risks for adults than children. Arsenic contribution towards 
ILCR for both children and adults was $91.3 \%$ and $87.6 \%$ in tap water and groundwater, respectively. Bottled water had a significantly $(\mathrm{p}<0.05)$ lower ILCR, compared with tap water and groundwater, attributable to extremely low levels of As in bottled water. There was no pronounced difference between tap water and groundwater in terms of cancer risks. The USEPA proposed a one out of one million chance of additional cancers as a management goal for risks posed by environmental contaminants $(\mathrm{Qu}, \mathrm{Li}, \mathrm{Wu}$, Wang, \& Giesy, 2015). Risks ranging from 1 out of 10,000 to 1 out of 1,000,000 are considered as acceptable, depending on the circumstances (Qu et al., 2015). A risk of $1 \times 10^{-3}$ will absolutely require protective measures (Pawełczyk, 2013). Compared with this risk range, the results of this study imply intolerable cancer risks for both children and adults due to heavy metals in drinking water over a lifetime. The ILCR method for calculating cancer risk estimates the incremental increase in risk for the exposed populations over a lifetime, but does not consider when the cancer will occur (Charnley \& Putzrath, 2001). Exposure to cancer-causing chemicals in food, water, air, and consumer products early in life can lead to cancer later in life (Carpenter \& Bushkin-Bedient, 2013). Therefore, prevention of early life exposure to cancer agents is essential.

Table 8. Incremental lifetime cancer risks for the children and adult populations of Kampala city through consumption of drinking water

\begin{tabular}{lllllll}
\hline \multirow{2}{*}{ Element } & \multicolumn{2}{c}{ Tap water } & \multicolumn{2}{c}{ Groundwater-fed protected spring } & \multicolumn{2}{c}{ Bottled water } \\
\cline { 2 - 7 } & Children & adults & Children & Adults & Children & Adults \\
\hline $\mathrm{As}$ & $9.03 \times 10^{-5}$ & $1.94 \times 10^{-4}$ & $8.57 \times 10^{-5}$ & $1.84 \times 10^{-4}$ & 0 & 0 \\
$\mathrm{~Pb}$ & $8.63 \times 10^{-6}$ & $1.85 \times 10^{-5}$ & $1.22 \times 10^{-5}$ & $2.61 \times 10^{-5}$ & $8.50 \times 10^{-6}$ & $1.82 \times 10^{-5}$ \\
\hline$\sum \mathrm{ILCR}$ & $9.90 \times 10^{-5}$ & $2.12 \times 10^{-4}$ & $9.79 \times 10^{-5}$ & $2.10 \times 10^{-4}$ & $8.50 \times 10^{-6}$ & $1.82 \times 10^{-5}$ \\
\hline
\end{tabular}

ILCR: Incremental lifetime cancer risks

\section{Conclusion}

Tap water, groundwater-fed protected spring and bottled drinking water in Kampala was contaminated with heavy metals making it a health concern. Bottled water had low $\mathrm{Pb}$ levels compared to groundwater-fed protected spring and tap water. The concentration of other elements detected in drinking water was too low to present a health risk to consumers. All drinking water sources showed high hazard indices indicating unacceptable risk of non-carcinogenic adverse health effects. Compared with other elements, lead contribution towards the hazard index was highest in all cases. Excess lifetime cancer risks via the oral route revealed intolerable cancer risks for both children and adults due to heavy metals in drinking water over a 70-year lifetime. Arsenic, in particular, contributed most to the total incremental lifetime cancer risks in tap water and groundwater-fed protected springs. It is therefore conclusive that children, pregnant women and women of childbearing age in Kampala are at high risk of heavy metal poisoning from drinking water. There is need to update the current National policy on environmental management in order to control the influx of heavy metals in drinking water sources. Government water bodies and water bottling companies should adopt multi-purpose water and wastewater treatment procedures for effective purification of drinking water.

\section{References}

Abdullahi, S., Ndikilar, C. E., Suleiman, A. B., \& Hafeez, H. Y. (2016). Assessment of Heavy Metals and Radioactivity Concentration in Drinking Water Collected From Local Wells and Boreholes of Dutse Town, North West, Nigeria. Journal of Environment Pollution and Human Health, 4(1), 1-8. https://doi.org/10.12691/jephh-4-1-1

Adamu, C., Nganje, T., \& Edet, A. (2015). Heavy metal contamination and health risk assessment associated with abandoned barite mines in Cross River State, southeastern Nigeria. Environmental Nanotechnology, Monitoring \& Management, 3, 10-21. http://dx.doi.org/10.1016/j.enmm.2014.11.001

Afiukwa, J. N. (2013). Evaluation and correlation study of heavy metals load in drinking water and update of water-related disease cases in Ebonyi State from 2001 -2011. American Journal of Scientific and Industrial Research, 4(2), 221-225. https://doi.org/10.5251/ajsir.2013.4.2.221.225

Ahoulé, D. G., Lalanne, F., Mendret, J., Brosillon, S., \& Maïga, A. H. (2015). Arsenic in African Waters: A Review. Water, Air, \& Soil Pollution, 226, 302. http://dx.doi.org/10.1007/s11270-015-2558-4

Akkus, C., \& Ozdenerol, E. (2014). Exploring Childhood Lead Exposure through GIS: A Review of the Recent Literature. International Journal of Environmental Research and Public Health, 11, 6314-6334. http://dx.doi.org/10.3390/ijerph110606314 
Bamuwamye, M., Ogwok, P., \& Tumuhairwe, V. (2015). Cancer and Non-cancer Risks Associated With Heavy Metal Exposures from Street Foods: Evaluation of Roasted Meats in an Urban Setting. Journal of Environment Pollution and Human Health, 3(2), 24-30. https://doi.org/10.12691/jephh-3-2-1

Carpenter, D. O., \& Bushkin-Bedient, S. (2013). Exposure to Chemicals and Radiation During Childhood and Risk for Cancer Later in Life. Journal of Adolescent Health, 52, S21-S29. http://dx.doi.org/10.1016/j.jadohealth.2013.01.027.

Charnley, G., \& Putzrath, R. M. (2001). Children's Health, Susceptibility, and Regulatory Approaches to Reducing Risks from Chemical Carcinogens. Environmental Health Perspectives, 109, 187-192. http://ehpnet1.niehs.nih.gov/docs/2001/109p187-192charnley/abstract.html

El-Sayed, M., \& Salem, W. M. (2015). Hydrochemical assessments of surface Nile water and ground water in an industry area-South West Cairo. Egyptian Journal of Petroleum, 24, 277-288. https://doi.org/10.1016/j.ejpe.2015.07.014

European Union (EU). (1998). Council Directive 98/83/EC of 3 November 1998 on the quality of water intended for human consumption. Official Journal of the European Communities (OJ L), 330, $42-45$

Fernández-Luqueño, F., López-Valdez, F., Gamero-Melo, P., Luna-Suárez, S., Aguilera-González, E. N., Martínez, A. I., Álvarez-Garza, M. A. (2013). Heavy metal pollution in drinking water - a global risk for human health: A review. African Journal of Environmental Science and Technology, 7(7), 567-584. http://dx.doi.org/10.5897/AJEST12.197

Fuhrimann, S., Stalder, M., Winkler, M. S., Niwagaba, C. B., Babu, M., Masaba, G., \& Cissé, G. (2015). Microbial and chemical contamination of water, sediment and soil in the Nakivubo wetland area in Kampala, Uganda. Environmental Monitoring and Assessment, 187(475), 15. http://dx.doi.org/10.1007/s10661-015-4689-x

Gaur, S., Singh, N., \& Saxena, S. (2011). Status of lead present in ground drinking water samples of Uttarakhand (Garhwal Region) in India. Asian Journal of Biomedical and Pharmaceutical Sciences, 1(1), 32-38.

Guerra, F., Trevizam, A. R., Muraoka, T., Marcante, N. C., \& Canniatti-Brazaca, S. G. (2012, January/February). Heavy metals in vegetables and potential risk for human health. Scientia Agricola, 69(1), 54-60. http://dx.doi.org/10.1590/S0103-90162012000100008

Hadiani, M. R., Dezfooli-manesh, S., Shoeibi, S., Ziarati, P., \& Khaneghah, A. M. (2014). Trace elements and heavy metals in mineral and bottled drinking waters on the Iranian market. Food Additives \& Contaminants: Part B, 07. http://dx.doi.org/10.1080/19393210.2014.947526

Hollamby, S., Afema-Azikuru, J., Sikarskie, J. G., Kaneene, J. B., Stuht, J. N., Fitzgerald, S. D., ... Rumbeiha, W. K. (2004). Clinical Pathology And Morphometrics of African Fish Eagles In Uganda. Journal of Wildlife Diseases, 40(3), 523-532. http://dx.doi.org/10.7589/0090-3558-40.3.523

Kolawole, S. E., \& Obueh, H. O. (2015). Evaluation of the minerals, heavy metals and microbial compositions of drinking water from different sourcesin Utagba-Uno, Nigeria. ISABB-Journal of Health and Environmental Sciences, 2(2), 6-10. http://dx.doi.org/10.5897/ISAAB-JHE2015.0017

Li, P.-H., Kong, S.-F., Geng, C.-M., Han, B., Lu, B., Sun, R.F., Bai, Z.-P. (2013). Assessing the Hazardous Risks of Vehicle Inspection Workers' Exposure to Particulate Heavy Metals in Their Work Places. Aerosol and Air Quality Research, 13, 255-265. http://dx.doi.org/10.4209/aaqr.2012.04.0087

Liu, X., Song, Q., Tang, Y., Li, W., Xu, J., Wu, J., Brookes, P. C. (2013). Human health risk assessment of heavy metals in soil-vegetable system: A multi-medium analysis. Science of the Total Environment, 463-464, 530-540. http://dx.doi.org/10.1016/j.scitotenv.2013.06.064

Mbabazi, J., Wasswa, J., Kwetegyeka, J., \& Bakyaita, G. K. (2010). Heavy metal contamination in vegetables cultivated on a major Urban wetland inlet drainage system of Lake Victoria, Uganda. International Journal of Enviromental studies, 67(3), 333-348. http://dx.doi.org/10.1080/00207231003612613

Mebrahtu, G., \& Zerabruk, S. (2011). Concentration of Heavy Metals in Drinking Water from Urban Areas of the Tigray Region, Northern Ethiopia. Momona Ethiopian Journal of Science, 3(1), 105-121. http://dx.doi.org/10.4314/mejs.v3i1.63689

Mghweno, L. R., Makokha, A. O., Magoha, H. S., Wekesa, J. M., \& Nakajugo, A. (2008). Environmental lead pollution and food safety around Kampala City in Uganda. Journal of Applied Biosciences, 12, 642-649.

Mkude, I. T. (2015). Comparative analysis of heavy metals from groundwater sources situated in Keko and 
Kigogo residential areas, Dar es Salaam. Journal of Water Resources and Ocean Science, 4(1), 1-5. https://doi.org/10.11648/j.wros.20150401.11

Muwanga, A., \& Barifaijo E (2006). Impact of industrial activities on the heavy metal loading and their physico-chemical effects on wetlands of Lake Victoria basin (Uganda). African Journal of Science and Technolology, 7(1), 51-63. http://dx.doi.org/10.4028/3-908158-03-6

Nigatu, W., Umuhire, C. A., Nsengimana, J., Nsabimana, A., \& Dieudonne, S. (2015). Quantitative Assessment of the Chemical Safety of Groundwater Wells in Two Selected Districts of Rwanda. International Journal of Environmental Protection and Policy, 3(4), 104-110. https://doi.org/10.11648/j.ijepp.20150304.14

Nyakairu, G. W., Muhwezi, G., \& Biryomumaisho, S. (2011). Assessment of Heavy Metals in Milk from Selected Dairy Farms and Shops in Wakiso District, Uganda. SUZA Journal of Natural and Social Science, $1(1), 36-52$.

Ogwok, P., Muyonga, J. H., \& Sserunjogi, M. L. (2009). Pesticide residues and heavy metals in Lake Victoria Nile perch, Lates niloticus, belly flap oil. Bulletin of Environmental Contamination and Toxicology, 82(5), 529-33. http://dx.doi.org/10.1007/s00128-009-9668-x

Okot-Okumu, J., \& Nyenje R. (2011). Municipal solid waste management under decentralisation in Uganda. Habitat International, 35, 537-543. http://dx.doi. org/10.1016/j.habitatint.2011.03.003

Oosterveer, P., \& Van-Vliet, B. (2010). Environmental Systems and Local Actors: Decentralizing Environmental Systems and Local Actors: Decentralizing. Environmental Management, 45, 284-295. http://dx.doi.org/10.1007/s00267-009-9423-4

Opio, C. (2012). Building effective drinking water management policies in rural Africa: Lessons from Northern Uganda. Discussion paper series No. 6. Ontario, Canada: Africa Initiative and The Centre for International Governance Innovation (CIGI ). Retrieved from www.africaportal.org

Orisakwe, O. E. (2014). Lead and Cadmium in Public Health in Nigeria: Physicians Neglect and Pitfall in Patient Management. North American Journal of Medical Sciences, 6(2), 61-70. http://dx.doi.org/10.4103/1947-2714.127740

Oyoo-Okoth, E., Wim, A., Osano, O., Kraak, M. H., Ngure, V., Makwali, J., \& Orina, P. (2010). Use of the fish endoparasite Ligula intestinalis (L., 1758) in an intermediate cyprinid host (Restreneobola argentea) for biomonitoring heavy metal contamination in Lake Victoria, Kenya. Lakes \& Reservoirs: Research and Management, 15, 63-73. http://dx.doi.org/10.1111/j.1440-1770.2010.00423.x

Pawełczyk, A. (2013). Assessment of health risk associated with persistent organic pollutants in water. Environmental Monitoring and Assessment, 185, 497-508. http://dx.doi.org/10.1007/s10661-012-2570-8

Qu, C., Li, B., Wu, H., Wang, S., \& Giesy, J. P. (2015). Multi-pathway assessment of human health risk posed by polycyclic aromatic hydrocarbons. Environmental Geochemistry and Health. http://dx.doi.org/10.1007/s10653-014-9675-7

Sankar, T. R., \& Rao, P. T. (2014). Heavy metal assessment in industrial groundwater in and around vijayawada, andhra pradesh, india. European Chemical Bulletin, 3(10), 1008-1013. http://dx.doi.org/10.17628/ecb.2014.3.1008-1013

Semuyaba, A. S., Segawa, I., \& Wamala, A. (2014). Potential Risk of Lead Toxicity from Bottled Water in Uganda. Makerere Pharmaceutical Journal, 12(1), e13-20.

Sun, C., Zhang, J., Ma, Q., \& Chen, Y. (2015). Human Health and Ecological Risk Assessment of 16 Polycyclic Aromatic Hydrocarbons in Drinking Source Water from a Large Mixed-Use Reservoir. International Journal of Environtal Research and Public Health, 12, 13956-13969. http://dx.doi.org/10.3390/ijerph121113956

UBOS. (2016). The National Population and Housing Census 2014 - Main Report. Kampala: Uganda Bureau of Statistics.

UNBS. (2014, 10 15). Uganda Standard . US EAS 12: 2014 (Potable water Specification), First Edition. Kampala: Uganda National Bureau of Standards. Retrieved from www.unbs.go.ug

USEPA. (1989). Risk Assessment Guidance for Superfund Volume 1: Human Health Evaluation (Part A). Springfield: US Department of Commerce, National Technical Information Service.

USEPA. (2009). United States Environmental Protetion Agency. Retrieved from Ground Water and Drinking 
Water: National Primary Drinking Water Regulations:

https://www.epa.gov/ground-water-and-drinking-water/national-primary-drinking-water-regulations

USEPA. (2016). United States Environmental Protection Agency (EPA). Retrieved from IRIS Chemical Assessment Quick list: https://cfpub.epa.gov/ncea/iris_drafts/simple_list.cfm?list_type=alpha

Van Straaten, P. 2000. Mercury contamination associated with small scale gold mining in Tanzania and Zimbabwe. Science of the Total Environment, 259, 105-113. http://dx.doi.org/10.1016/S0048-9697(00)00553-2

Wei, H., Le, Z., Shuxian, L., Dan, W., Xiaojun, L., Lan, J., \& Xiping, M. (2015). Health risk assessment of heavy metals and polycyclic aromatic hydrocarbons in soil at coke oven gas plants. Environmental Engineering and Management Journal, 14(2), 487-496. http://omicron.ch.tuiasi.ro/EEMJ/

WHO. (2008). Guidelines for drinking-water quality [electronic resource]: incorporating 1st and 2nd addenda, Vol.1, Recommendations. $3^{\text {rd }}$ edition. Geneva: World Health Organization (WHO).

Yu, B., Wang, Y., \& Zhou, Q. (2014). Human Health Risk Assessment Based on Toxicity Characteristic Leaching Procedure and Simple Bioaccessibility Extraction Test of Toxic Metals in Urban Street Dust of Tianjin, China. PLoS ONE, 9(3), e92459. http://doi.org/10.1371/journal.pone.0092459

\section{Copyrights}

Copyright for this article is retained by the author(s), with first publication rights granted to the journal.

This is an open-access article distributed under the terms and conditions of the Creative Commons Attribution license (http://creativecommons.org/licenses/by/3.0/). 